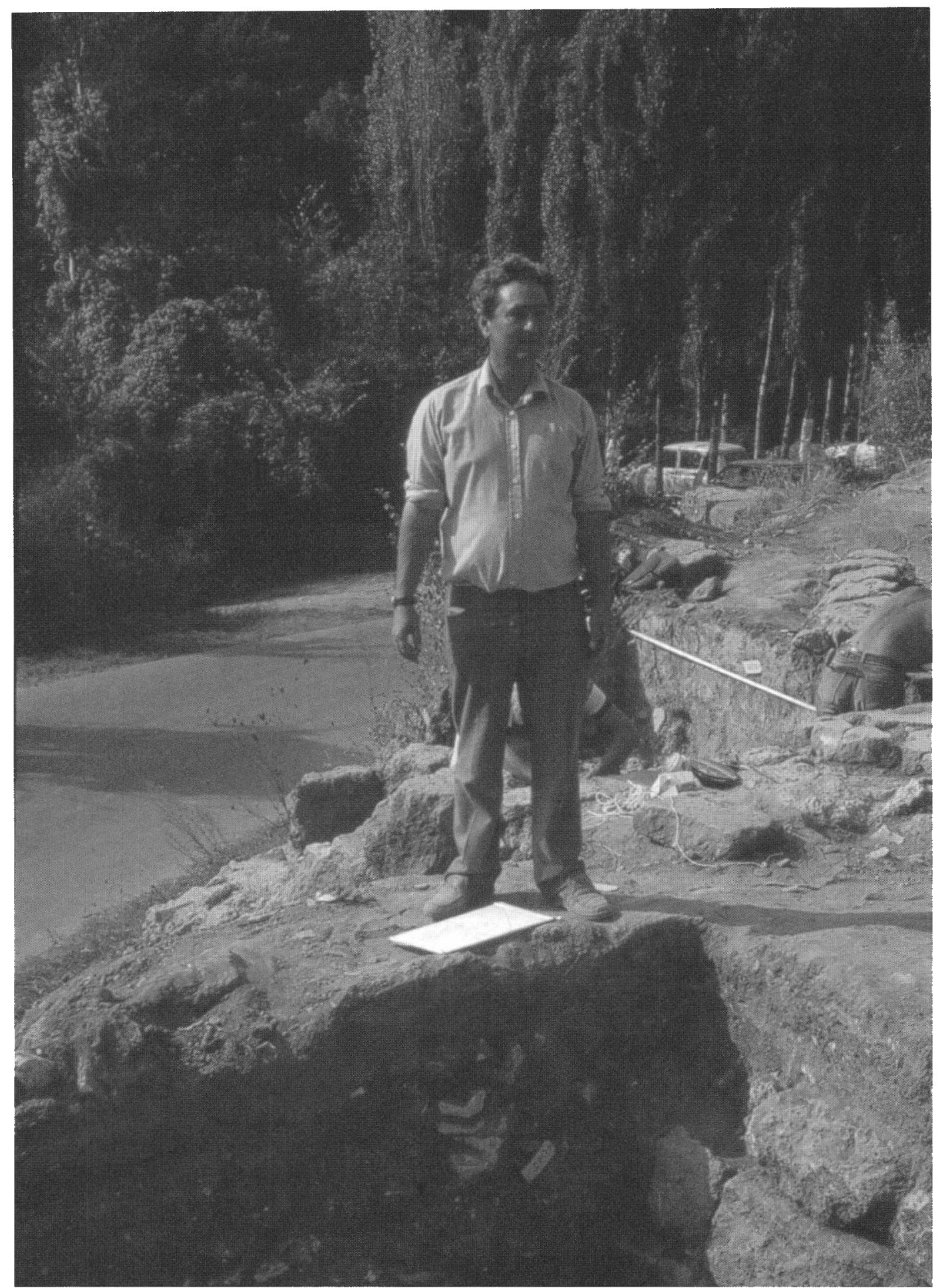

Tim Potter at his excavation at Mola di Monte Gelato, Italy. (Photo: Graeme Barker.) 


\section{OBITUARY: Dr T. W. Potter}

The millennium year has seen the sudden death, at the age of only 55, of Tim Potter, since 1995 Keeper of Prehistoric and Romano-British Antiquities at the British Museum. Tim was widely known and greatly respected for his exemplary record of excavation and publication not only of sites in Britain, but even more notably in Italy and Algeria. 'Tim's death has touched and saddened me more than anything I remember', a leading Italian scholar remarked to me, recognising that in Tim Italy had lost not only a sensitive interpreter of its Roman past, but also an enthusiastic champion of its present.

'Enthusiastic' and 'ebullient' are the adjectives most used to describe Tim in the numerous tributes published since his death. These qualities were particularly appreciated during Tim's work on the Roman Forum at Iol Caesarea (Cherchel, Algeria), excavated from 1977-1981 with Dr Nacéra Benseddik of the Algerian Antiquities Service. In 1980 , Cherchel was gravely affected by the disastrous earthquake that devastated the town of el-Asnam in the Atlas mountains to the south. I recall to this day watching from a bed, to which I had been temporarily confined following a bout of illness dramatically manifested on Tim's excavation dumps (an incident he enjoyed recalling in later years), the cracks visibly widening in the walls of the elderly villa, while the light fittings swayed alarmingly from the equally unstable ceiling. A visiting senior professor housed in grander quarters at Tipasa discreetly complained of nocturnal evacuation to a flower-bed, followed by a morning shave in lemonade. Tim, meanwhile, rightly declared that the Forum was the safest place to be: his infectious charm saw that we transient visitors were well cared for even during the privations of the earthquake, and the pace and interest of the excavation under his strong leadership distracted from any sense of fear and dismay.

Enormous patience and persistence were required to see this excavation through to publication (T. W. Potter and N. Benseddik, Fouilles du Forum de Cherchel, 1977-81, Alger 1993: the books were thereafter long sequestered). Meanwhile, for Tim there was an important spin-off: the revelation, coaxed from careful observation of late antique timber structures which had hitherto escaped attention, of the transformation of cities such as Iol Caesarea, a former royal capital long conscious of its distinguished past. Tim published his findings in Towns in Late Antiquity: Iol Caesarea and its Context (Occasional Publication no. 2 of the Ian Sanders Memorial Fund, University of Sheffield 1995), the expanded text of a memorial lecture given by Tim in 1990, and named for another Roman archaeologist snatched from us much too soon.

Tim's experiences in Algeria did not lead to further north African field projects, though this was not for want of trying. However, his friends and colleagues benefited enormously from Tim's perceptive understanding of the region and his acute judgement of how to manage the British contribution to fieldwork. Within the Society for Libyan Studies, Tim served on the Fieldwork Committee from its inception in 1994; more recently he acted with Professor Michael Fulford as External Archaeological Adviser; most poignantly, he replaced the late John Lloyd on the Publications Committee and the Council of Management, attending only one meeting before his own death. In these tasks he proved as assiduous and encouraging as in the many other commitments of a busy life.

We shall miss him terribly, but the memory of his extraordinary vitality will not be dimmed. I close with a vignette of Tim at Cherchel as remembered by our mutual friend and colleague Mahfoud Ferroukhi: 
'Tea time!' disait Tim. 'Tim time!' je répondais tous les jours à 10 heures du matin sur le forum de Cherchell. Je souriais, il aimait ma réplique.

Tim adorait ce moment ou il appelait toute l'équipe de fouille pour s'attabler et déguster un thé à la menthe au café du coin. Nous avons vécu ensemble durant plusieurs mois des années 1980, et l'image que je garde de notre regretté Tim c'est d'un homme joyeux et heureux de découvrir.

'Tu sais', me disait-il un soir d'octobre avec son accent british prononcé, 'c'est un hasard qui m'a fait venir à Cherchell, mais je découvre que je ne connaissais rien de l'Afrique du Nord et de ses traditions. Je suis un homme heureux.' Je souriais.

Je le regardai: la cigarette pendue au coin des lèvres, les yeux pétillants, plissés par son sourire éternel; les cheveux décoiffés à l'africaine, il se mit, comme à son habitude, à fredonner un air des Beatles qu'il aimait chanter. La reine et les Beatles revenaient souvent dans mes discussions avec Tim car il leur accordait un immense respect. Et là, il reprenait son air sérieux, les sourcils légèrement remontées, le regard direct sans toutefois effacer son sourire.

Sa rigeur scientifique et sa faculté d'adaptation à toutes les situations nous ont beaucoup apporté; les Cherchellois qui l'ont connu l'ont très vite adopté et apprécié.

Dorénavant, je ne garderai cette amitié que dans mes pensées. Quel regret, Tim.

Susan Walker

Forum excavations, Cherchel 1980

British Museum, London
Mahfoud Ferroukhi

Fouilles du forum de Caesarea

Mauretaniae, 1978-81

Ex-conservateur de Cherchell Sous-directeur de l'archéologie Algérie 